\title{
Phytoplankton and bacterial alkaline phosphatase activities in relation to phosphate and DOP availability within the Gironde plume waters (Bay of Biscay)
}

\author{
C. Labry' *, D. Delmas and A. Herbland ${ }^{1}$ \\ Centre de Recherche en Ecologie Marine et Aquaculture, CNRS-IFREMER, BP 5, 17137 L'Houmeau, \\ France

\footnotetext{
* Corresponding author. Present address: IFREMER/Département Ecologie Côtière BP 70, 29280 Plouzané, France. Tel.: +332 982249 14; fax: +33298224548.

${ }^{1}$ Present address: IFREMER/Laboratoire Aquacole de Calédonie (LAC Saint Vincent) BP 205998846 Nouméa Cedex, France
}

\begin{abstract}
Previous studies conducted on the continental shelf in the Southeast Bay of Biscay influenced by Gironde waters (one of the two largest rivers on the French Atlantic coast) showed the occurrence of late winter phytoplankton blooms and phosphorus limitation of algal growth thereafter. In this context, the importance of dissolved organic phosphorus (DOP) for both algae and bacteria was investigated in 1998 and 1999 in terms of stocks and fluxes. Within the mixed layer, although phosphate decreased until exhaustion from winter to spring, DOP remained high and phosphate monoesters made up between 11 to $65 \%$ of this pool. Total alkaline phosphatase activity (APA, Vmax) rose gradually from winter (2-8 nM h-1) to late spring (100-400 nM h-1), which was mainly due to an increase in specific phytoplankton (from 0.02 to $3.0 \mathrm{nmol} \mu \mathrm{gC}-1 \mathrm{~h}-1$ ) and bacterial APA (from 0.04 to $4.0 \mathrm{nmol} \mu \mathrm{gC}-1 \mathrm{~h}-1$ ), a strategy to compensate for the lack of phosphate. At each season, both communities had equal competitive abilities to exploit DOP but, taking into account biomass, the phytoplankton community activity always dominated (57-63\% of total APA) that of bacterial community (9-11\%). The dissolved APA represented a significant contribution. In situ regulation of phytoplanktonic APA by phosphate (induction or inversely repression of enzyme synthesis) was confirmed by simultaneously conducted phosphate-enrichment bioassays. Such changes recorded at a time scale of a few days could partly explain the seasonal response of phytoplankton communities to phosphate depletion.
\end{abstract}

Keywords: Alkaline phosphatases; Bacteria; DOP; Gironde; Phosphate; Phytoplankton 


\section{ABSTRACT}

Previous studies conducted on the continental shelf in the Southeast Bay of Biscay influenced by Gironde waters (one of the two largest rivers on the French Atlantic coast) showed the occurrence of late winter phytoplankton blooms and phosphorus limitation of algal growth thereafter. In this context, the importance of dissolved organic phosphorus (DOP) for both algae and bacteria was investigated in 1998 and 1999 in term of stocks and fluxes. Within the mixed layer, although phosphate decreased until exhaustion from winter to spring, DOP remained high and phosphate monoesters made up between 11 to $65 \%$ of this pool. Total alkaline phosphatase activity (APA, $\mathrm{V}_{\max }$ ) rose gradually from winter (2-8 $\mathrm{nM} \mathrm{h} \mathrm{h}^{-1}$ ) to late spring (100-400 $\mathrm{nM} \mathrm{h}^{-1}$ ), which was mainly due to an increase in specific phytoplankton (from 0.02 to $3.0 \mathrm{nmol} \mu \mathrm{gC}^{-1} \mathrm{~h}^{-1}$ ) and bacterial APA (from 0.04 to $4.0 \mathrm{nmol} \mu \mathrm{gC}^{-1} \mathrm{~h}^{-1}$ ), a strategy to compensate for the lack of phosphate. At each season, both communities had equal competitive abilities to exploit DOP but, taking into account biomass, the phytoplankton community activity always dominated (57-63\% of total APA) that of bacterial community (911\%). The dissolved APA represented a significant contribution. In situ regulation of phytoplanktonic APA by phosphate (induction or inversely repression of enzyme synthesis) was confirmed by simultaneously conducted phosphate-enrichment bioassays. Such changes recorded at a time scale of a few days could partly explain the seasonal response of phytoplankton communities to phosphate depletion.

KEY WORDS: Alkaline phosphatases. Phosphate. DOP. Phytoplankton. Bacteria. Gironde 


\section{INTRODUCTION}

The ability of microorganisms to acquire phosphorus (P) from dissolved organic phosphorus (DOP) compounds, requires the action of phosphatases, catalyzing the hydrolysis of phosphate monoesters and liberating inorganic phosphate and organic matter. Part of this released phosphate could be taken up directly by microorganisms since phosphatases are membrane-bound or located in the periplasmatic space (coupled uptake) (Cembella et al., 1984). Considerable parts of APA are dissolved and contribute to the phosphate pool which is not directly taken up. Alkaline phosphatases, the most active in marine waters, hydrolyse a wide range of organic $\mathrm{P}$ compounds due to their low specificity for organic moiety compared to more specific phosphatases such as 5'-nucleotidases (Ammerman and Azam, 1985). In addition, alkaline phosphatase activity (APA) was shown to be sensitive to phosphate availability and particularly to the intracellular phosphate pool of microorganisms (Gage and Gorham, 1985; Myklestad and Sakshaug, 1983). As a result, it has often been used as an indicator of the phosphorus nutritional status of phytoplankton communities. As such an indicator, it has largely been used in lake waters where phosphorus was generally the limiting factor of microbial communities (Berman, 1970; Pettersson and Jansson, 1978); on the contrary few studies have been conducted in marine waters (Hoppe 2003) even though a recent surge in interest has been pointed out (Sebastian et al., 2004; Hoppe and Ullrich, 1999; Li et al., 1998; Nausch, 1998). However, few surveys gather APA, DOP, phosphate monoesters (Hydrolysable DOP) and phosphate data in marine systems on a seasonal scale compared to previous studies in lake waters (Chrost and Overbeck, 1987).

APA studies have mainly focused on algae (Fitzgerald and Nelson, 1966) and have scarcely dealt with bacterial activities even though bacteria are also known to have significant APA (Martinez and Azam, 1993). Most papers, including recent ones, have evaluated total APA on unfiltered samples (Hoppe and Ullrich, 1999; Nausch, 1998) or separate particulate and dissolved APA, taking into account that algae or bacteria comprise the bulk of particulate APA (Rose and Axler, 1998). Some studies have evaluated APA from different plankton fractions (Gambin et al., 1999; Gonzalez-Gil et al., 1998) but surveys dealing with simultaneously algal and bacterial fractions are relatively scarce (Chrost and Overbeck, 1987). Even if size fractionation by filtration is never completely satisfying (overlapping size) it gives useful indications as regards the major microorganisms contributing to APA. 
The Spanish coast of the Bay of Biscay with its weak and localized freshwater inputs (OSPAR, 2000) is characterized by spring phytoplankton blooms dominated by diatoms (Varela, 1996) which is a classic setting like the phytoplankton dynamics in the temperate waters in the North Atlantic (Longhurst, 1998). Until now, this scheme was applied to the whole Bay of Biscay. The French continental shelf is characterized by significant freshwater inputs from large rivers (Gironde and Loire, annual mean water outflows of $900 \mathrm{~m}^{3} \mathrm{~s}^{-1}$ ); however the biological production of these waters is largely unknown. Previous studies conducted in the Gironde plume waters pointed out that spring phytoplankton blooms actually did occur (May 1995). However, they were atypical with a size distribution of chlorophyll $a$ (chl a) and primary production dominated by small cells $(<3 \mu \mathrm{m})$, already severely phosphorus (P) limited (Herbland et al., 1998), and grazed daily by microzooplankton (Sautour et al., 2000). In a first paper (Labry et al., 2001), we highlighted the occurrence of winter blooms in the Gironde plume, with the same characteristics as typical spring blooms in temperate waters. In a second paper (Labry et al., 2002), we confirmed that algal growth was phosphorus limited at the end of the winter blooms and in spring. This early $\mathrm{P}$ limitation favoured the development of small cells at the beginning of spring and the subsequent presence of spring blooms composed of pico and nanophytoplankton (as in May 1995), which ultimately acts upon the nature of the whole plankton food web.

The objectives of the present paper are to evaluate the seasonal importance of DOP in terms of stocks (evaluation of hydrolysable DOP) and fluxes (APA) for phytoplankton and bacterial communities in the Gironde plume by in situ measurements and in vitro bioassays simultaneously conducted, simulating phosphate depleted and phosphate repleted conditions.

\section{MATERIALS AND METHODS}

\section{Sampling strategy}

Six cruises were carried out in 1998 and 1999 from early winter to late spring (see Labry et al., 2002 for their names and dates). They were composed of a grid of stations covering the spread of the Gironde plume or a part of the plume where sampling using conventional parameters (nutrients, chl $a$, bacteria numbers, particulate organic phosphorus POP and DOP) was carried out within the water column. In addition to the usual parameters, determination of APA and their kinetic parameters as well as phosphate enrichment bioassays were conducted on additional stations which were characteristics of the Gironde plume. The criterion to select 
stations was the salinity of the mixed layer : it was chosen to be below 34.5 and above 32 (generally found close to the Gironde mouth) to avoid respectively too "oceanic" characteristics and too "estuarine” features. The precise salinity was chosen to be the salinity the more representative of the Gironde plume hydrology at each period. We present results from the latter stations represented in Fig. 1. The stations on each cruise were not marked out since the distance between the stations and the river mouth was not indicative of the P supply from the river which depended on many characteristics (river runoffs, winds, turbidity...). From winter to late spring, the mean temperatures of the mixed layer were $12,11.5,16.9^{\circ} \mathrm{C}$ in 1998 and $10,12.3,16.7^{\circ} \mathrm{C}$ in 1999 . The mixed layer was separated from the underlying layer of salinity > 35 by a halocline in March 1998 and late February 1999 and a thermohalocline in June 1998, late April and late May 1999. 
Fig. 1. Study site with locations of the different stations (some are surimposed) for all cruises in 1998 and 1999.

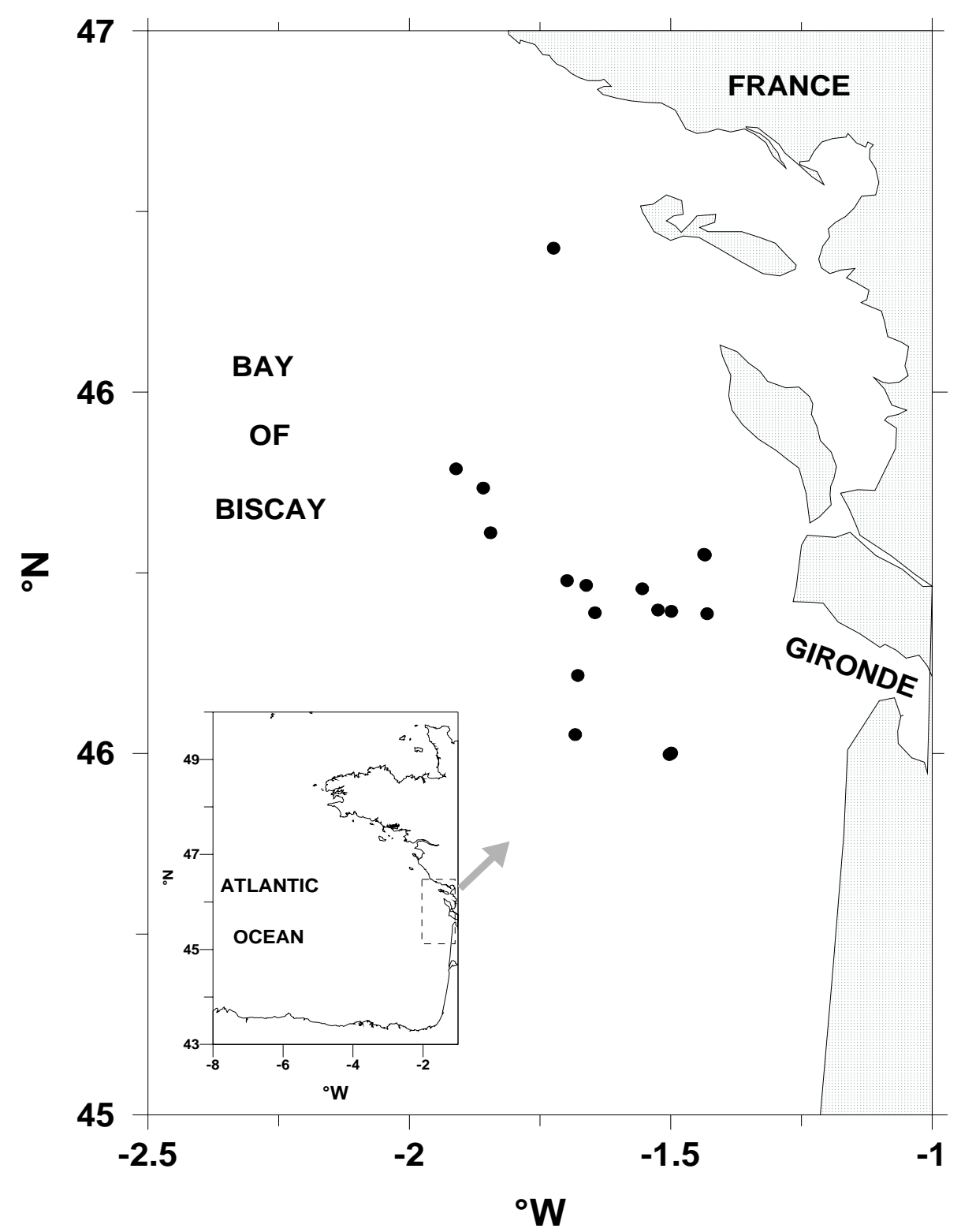

\section{Chemical and biological variables}

chl $a$ and bacterial counts

Total chl $a$ and pheopigments were determined in particulate organic matter collected in 25 $\mathrm{mm}$ Whatman GF/F and additional filtrations in $1 \mu \mathrm{m}$ polycarbonate Nuclepore filters were undertaken in June 1998 and in 1999. The filters were frozen $\left(-20^{\circ} \mathrm{C}\right)$ and analysed later by acidification fluorometric procedure in $90 \%$ acetone extracts or in $100 \%$ methanol extracts (Wright et al., 1997). Phytoplankton carbon was estimated from chl a concentrations 
assuming a constant C:chl $a$ w:w ratio of 50:1. Samples for bacterial counts were preserved with borate buffered formalin (2\% final concentration). Bacteria were enumerated by direct counting after staining with DAPI (Porter and Feig, 1980) with an epifluorescence microscope (excitation BP 340-380 nm Leitz, emission LP $430 \mathrm{~nm}$ Leitz). Bacteria numbers were converted into bacterial carbon assuming a standard cell content of $16 \mathrm{fg} C$ which corresponded to the range of values (10-18 fg C) previously measured by Artigas (1998) in the Gironde plume waters. In 1999, autotrophic bacteria were separately enumerated from heterotrophic ones by using a green excitation filter $(450-490 \mathrm{~nm})$ : cyanobacteria appear to be red whereas heterotrophic bacteria are invisible (Caron, 1983).

\section{Dissolved and particulate phosphorus}

For phosphate determination, seawater samples were filtered using Whatman GF/F with a syringe filtration system. The phosphate was analysed on board immediately after sampling with a spectrophotometer (Shimadzu UV 160) with a $10 \mathrm{~cm}$ optical path cell according to the method described by Strickland and Parsons (1972) with the detection limit of $20 \mathrm{nM}$. POP, DOP and phosphate monoester concentrations were measured after seawater filtration through acid-washed ( $\mathrm{HCl} 1 \mathrm{~N}$ ) precombusted (12 hours at $400{ }^{\circ} \mathrm{C}$ ) Whatman GF/F in 1998 and through $0.2 \mu \mathrm{m}$ Nuclepore polycarbonate filters in 1999. The filters and filtrates were immediately frozen $\left(-20^{\circ} \mathrm{C}\right)$ and stored in acid-washed $(\mathrm{HCl} 1 \mathrm{~N})$ precombusted glass flasks. Analyses of DOP and POP were carried out by the persulfate oxidation procedure (Valderrama, 1981). After oxidation, orthophosphate concentrations were determined using an autoanalyser (Skalar), providing either the total dissolved phosphorus (TDP) or directly the POP data. DOP was obtained by subtracting the phosphate initially present (see above) from TDP.

Phosphate monoesters were determined in 1999 according to the method of Strickland and Parsons (1972) based on hydrolysis by adding pure Escherichia coli alkaline phosphatase. This enzyme activity has been found to be significantly inhibited from $1.6 \mu \mathrm{M}$ of phosphate (Chrost et al., 1986), very different from phosphate concentrations of our samples $(<0.5 \mu \mathrm{M})$. $50 \mathrm{ml}$ of sample was incubated with $1 \mathrm{ml}$ of Tris buffer solution (pH 8.00) and $1 \mathrm{ml}$ of pure Escherichia coli alkaline phosphatase (EC 3.1.3.1) solution $\left(0.2 \mathrm{U} \mathrm{ml}^{-1}\right)$ at $30^{\circ} \mathrm{C}$ for 2 hours. The phosphate was determined immediately using a spectrophotometer (Shimadzu UV 160) with a $10 \mathrm{~cm}$ optical path cell and was subtracted from the phosphate initially present to 
obtain phosphate monoesters. Any phosphate present in the buffer and the enzyme solution was determined by carrying out a blank determination on $50 \mathrm{ml}$ of MilliQ water. For each series of measurements, a sample with $1 \mu \mathrm{M}$ glucose-6-phosphate was also processed to check a $100 \%$ enzymatic yield.

\section{Alkaline phosphatase activity (APA)}

The fluorometric method with methylumbelliferyl phosphate (MUF-P) as substrate (Hoppe, 1983) was used on unfiltered (total APA) and two prefiltered ( $<0.2 \mu \mathrm{m}$ APA and $<1 \mu \mathrm{m}$ APA) seawater samples. We used a saturating concentration of MUF-P (250 $\mu \mathrm{M})$ to reach the maximum activity $\left(\mathrm{V}_{\max }\right)$ providing the enzymatic potentialities of microorganisms and enabling comparisons between different depths, stations and seasons. In addition, we determined the kinetic parameters $\left(\mathrm{K}_{\mathrm{m}}\right.$ and $\left.\mathrm{V}_{\max }\right)$ in 1999 for one depth within the mixed layer, using gradual MUF-P concentrations (0.5, 1, 2, 4, 8, 16, 32, 63, 125 and $250 \mu \mathrm{M}) .2 \mathrm{ml}$ samples and controls (supplemented by $4 \%$ formaldehyde) were incubated in duplicates with $50 \mu \mathrm{l}$ of substrate solution for ten hours. Incubations in the dark respected in situ temperatures and $\mathrm{pH}$. Hydrolysis was stopped by the addition of $4 \%$ formaldehyde, then the samples and controls were frozen $\left(-20^{\circ} \mathrm{C}\right)$. Preliminary tests carried out within the Gironde plume waters showed linear hydrolysis for at least 24 hours and total APA inhibition with $4 \%$ formaldehyde. The fluorescence produced by the released methylumbelliferon MUF (excitation at $365 \mathrm{~nm}$ and emission at $460 \mathrm{~nm}$ ) was measured by flow injection analysis (Delmas et al., 1994), composed of a pump, an injection valve and a fluorescence spectrometer (Kontron SFM 25) previously calibrated with MUF solutions (2nM to $2 \mu \mathrm{M}$ ), thus avoiding problem of fluorescence-quenching of samples. The kinetic parameters $\mathrm{K}_{\mathrm{m}}$, $\mathrm{V}_{\text {max }}$ were calculated using non linear, least squares regression of data fitted to the Michaelis and Menten equation, using the Marquardt-Levenberg algorithm (Brooks, 1992). The MUF-P turnover time was estimated by the $\mathrm{K}_{\mathrm{m}}: \mathrm{V}_{\max }$ ratio. The specific phytoplankton and bacterial APA were estimated by dividing respectively $>1 \mu \mathrm{m}$ APA and 0.2-1 $\mu \mathrm{m}$ APA by phytoplankton and bacterial carbon.

\section{Phosphate-enrichment bioassays}

On board enrichment bioassays were conducted in 1999 on seawater collected from the mixed layer and divided between two 25 liter polycarbonate bottles (sample and control). The

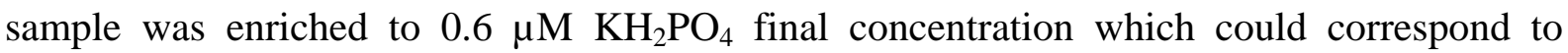


phosphate enrichment from winter vertical mixing in the Gironde plume for salinity 32. Incubations were performed at in situ temperatures (with running surface seawater) and at incident light conditions (late February) or $40 \%$ of incident light (late April and May). Water samples were taken periodically for the measurement of chl $a$, phosphate and APA.

\section{RESULTS}

The general trends from the stations presented in this paper were in accordance with those from the grid of stations, concerning chl $a$, bacteria numbers, phosphate, DOP, POP (see Labry et al., 2002). Phytoplankton dynamics was characterized by late winter blooms of diatoms and late spring blooms of pico-nanophytoplankton although bacterial biomass did not change throughout the seasons (Table 1).

Table 1. Mean concentrations $\pm 95 \%$ confidence interval of chl $a$, bacterial counts, phytoplankton and bacterial carbon, assuming respectively a constant C:chl $a$ w:w ratio of 50:1 and a constant cell content of 16 fg C, within the mixed layer of the Gironde plume in 1998 and 1999. Values in brackets are number of samples.

\begin{tabular}{|c|c|c|c|c|}
\hline & $\operatorname{chl} a\left(\mu \mathrm{g} \mathrm{I}^{-1}\right)$ & Cphyto ( $\mu g \mathrm{Cl}^{-1}$ ) & Bact $\left(10^{6}\right.$ cells $\left.\mathrm{ml}^{-1}\right)$ & Cbact $\left(\mu g C \mathrm{I}^{-1}\right)$ \\
\hline \multicolumn{5}{|l|}{1998} \\
\hline January & $0.56 \pm 0.05(10)$ & $28 \pm 3(10)$ & $0.62 \pm 0.05(10)$ & $10 \pm 1(10)$ \\
\hline March & $1.12 \pm 0.29(8)$ & $56 \pm 15(8)$ & $0.62 \pm 0.09$ & $10 \pm 2(8)$ \\
\hline June & $2.41 \pm 0.38(8)$ & $120 \pm 19(8)$ & $0.85 \pm 0.11(8)$ & $14 \pm 2(8)$ \\
\hline \multicolumn{5}{|l|}{1999} \\
\hline Late February & $1.53 \pm 0.53$ & $77 \pm 28(3)$ & $0.62 \pm 0.09$ & $10 \pm 2(3)$ \\
\hline Late April & $0.41 \pm 0.04$ & $20 \pm 2(3)$ & $0.53 \pm 0.15$ & $8 \pm 2(3)$ \\
\hline Late May & $1.39 \pm 0.54(4)$ & $70 \pm 26(4)$ & $0.69 \pm 0.28$ & $11 \pm 4(4)$ \\
\hline
\end{tabular}

\section{Seasonal evolution of phosphorus compounds}

There was a pronounced seasonal variation in phosphate within the Gironde plume mixed layer in 1998 and 1999 with high concentrations in early winter (Fig. 2, Table 2) then exhausted concentrations $(<0.02 \mu \mathrm{M})$ from late winter to late spring, even though continuous Gironde phosphate supplies may have occurred. DOP remained at relatively high concentrations in 1998 and 1999 ranging between 0.1 and $0.4 \mu \mathrm{M}$ on the whole water column (Table 2), except in March 1998, when markedly higher values were recorded (0.628 $\mu \mathrm{M})$. POP showed a slight decrease between January and March 1998, between late February and late April 1999 but relatively high values in June 1998 and in late May 1999 (Table 2). 
Phosphate monoesters presented homogeneous vertical distribution at each period and represented 34, 11 and $65 \%$ of the DOP pool in late February, late April and late May respectively (Table 2).

Table 2. Mean concentrations $\pm 95 \%$ confidence interval $(\mu \mathrm{M})$ of phosphate, DOP, POP and $\mathrm{PO}_{4}$ monoesters within the mixed layer of the Gironde plume in 1998 and 1999. Because of homogeneous vertical distribution, $\mathrm{PO}_{4}$ monoesters were averaged within the entire water column. Values in brackets are number of samples.

\begin{tabular}{ccccc}
\hline & PO $_{4}$ & DOP & POP & PO $_{4}$ monoesters \\
\hline $\mathbf{1 9 9 8}$ & & & & \\
January & $0.334 \pm 0.053(10)$ & $0.262 \pm 0.069(10)$ & $0.099 \pm 0.046(10)$ & - \\
March & $0.001 \pm 0.003(8)$ & $0.628 \pm 0.155(8)$ & $0.067 \pm 0.042(8)$ & - \\
June & $0.003 \pm 0.006(8)$ & $0.184 \pm 0.060(7)$ & $0.166 \pm 0.026(8)$ & - \\
\hline $\mathbf{1 9 9 9}$ & & & & \\
Late February & $0.118 \pm 0.155(3)$ & $0.203 \pm 0.084(3)$ & $0.116 \pm 0.024(3)$ & $0.075 \pm 0.016(7)$ \\
Late April & $0.006 \pm 0.010(3)$ & $0.262 \pm 0.030(3)$ & $0.089 \pm 0.040(3)$ & $0.036 \pm 0.011(5)$ \\
Late May & $0.008 \pm 0.019(4)$ & $0.173 \pm 0.056(4)$ & $0.172 \pm 0.046(4)$ & $0.111 \pm 0.011(8)$ \\
\hline
\end{tabular}


Fig. 2. Profiles of phosphate and total APA in the Gironde plume in 1998 (filled circle) and 1999 (open circle). The mixed layer was located at 10-20 meters throughout the study period.
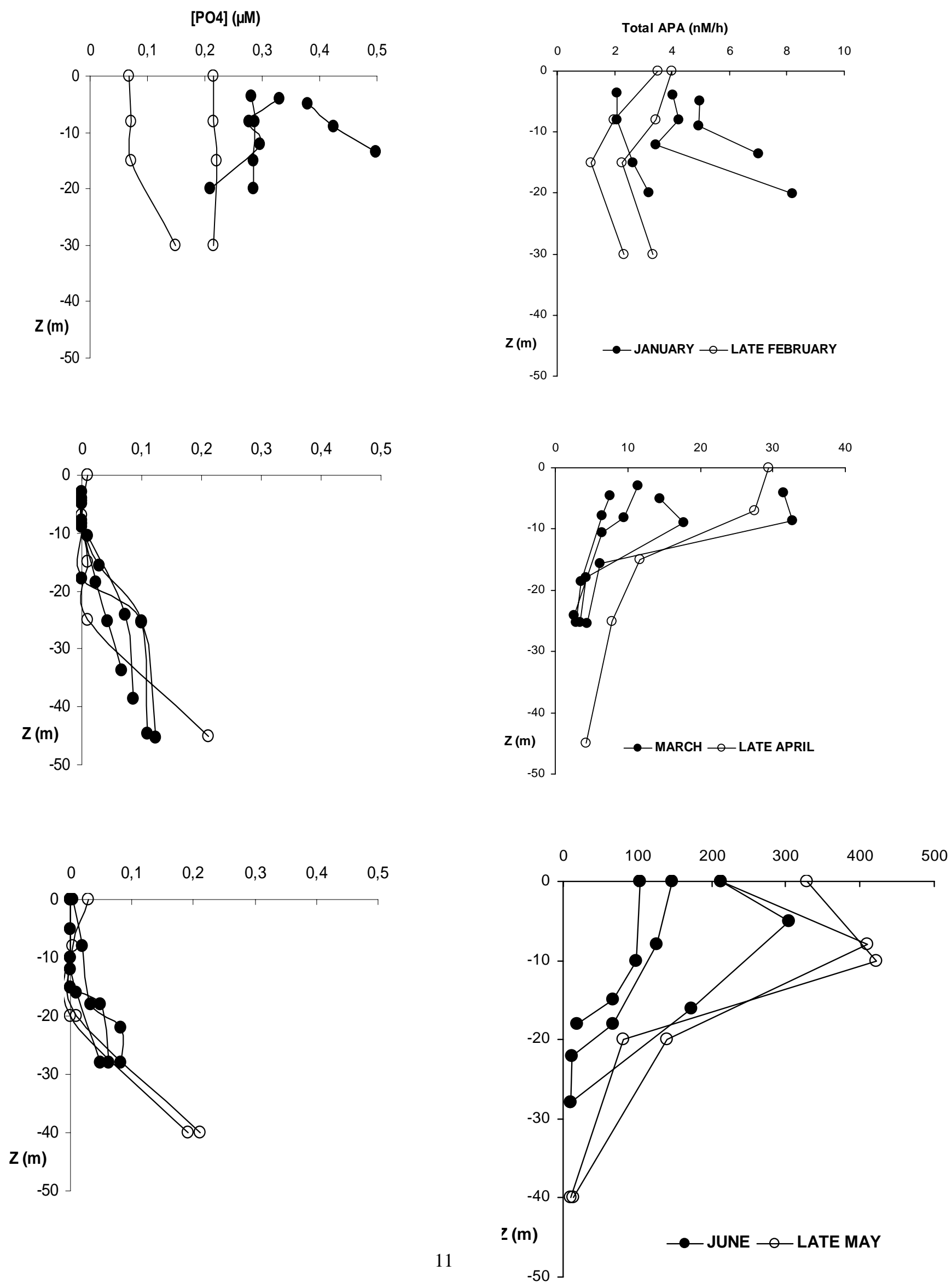


\section{Seasonal evolution of total and size-fractionated APA}

Generally, total APA was high within the mixed layer and decreased in the bottom waters (Fig. 2). Its seasonal evolution within the Gironde plume mixed layer showed a similar pattern in 1998 and 1999 : low activities in winter (from 2 to $8 \mathrm{nM} \mathrm{h}^{-1}$ ), increasing in early spring ( 5 to $35 \mathrm{nM} \mathrm{h}^{-1}$ ) and very high values in late spring (100 to $400 \mathrm{nM} \mathrm{h}^{-1}$ ). 0.2-1 $\mu \mathrm{m}$ and $>1 \mu \mathrm{m}$ APA showed the same seasonal evolution and their contributions to total APA were unchanged and similar throughout 1998 and 1999 (Table 3) : the $>1 \mu \mathrm{m}$ fraction dominated (63 $\pm 17 \%$ in 1998 and $57 \pm 8 \%$ in 1999) whereas $0.2-1 \mu \mathrm{m}$ fraction displayed the smallest contribution (9 $\pm 6 \%$ and $11 \pm 5 \%$ ). $>1 \mu \mathrm{m}$ and 0.2-1 $\mu \mathrm{m}$ fractions described adequately respective algal and bacterial activities in our samples according to weak chl $a<1 \mu \mathrm{m}$ (13\% of total Chla in June 1998 and only -5, 7 and $1 \%$ of total Chla from winter to spring 1999) and cyanobacteria biomass (less than 3 \% of the overall bacteria biomass in 1999). The potential importance of attached bacteria to $>1 \mu \mathrm{m}$ particles seem to have been insignificant relative to those of free cells (see Discussion). Since an increase in APA could mean an increase in biomass, APA was roughly divided by the biomass of both phytoplankton and bacteria. The two specific activities also increased gradually from winter to late spring 1998 and 1999 (Table 3) and during each period these phytoplankton and bacterial activities were similar.

Table 3. Relative size contribution (mean $\pm 95 \%$ confidence interval) to total APA and specific phytoplankton and bacterial APA within the mixed layer of the Gironde plume in 1998 and 1999. Values in brackets are number of samples.

\begin{tabular}{cccccc}
\hline & \multicolumn{2}{c}{ Contribution to total APA (\%) } & \multicolumn{2}{c}{ Specific APA (nmol $\left.\mathbf{~ g C}^{-\mathbf{1}} \mathbf{h}^{\mathbf{- 1}}\right)$} \\
\hline $\mathbf{1} \mathbf{\mu \mathbf { m }}$ & $\mathbf{0 . 2 - 1} \mathbf{\mu m}$ & $<\mathbf{0 . 2} \mathbf{~ \mathbf { m }}$ & Phyto & Bact \\
\hline $\mathbf{1 9 9 8}$ & & & & & \\
January & $48 \pm 14(10)$ & $8 \pm 9(10)$ & $44 \pm 17(10)$ & $0.06 \pm 0.02(10)$ & $0.05 \pm 0.04(7)$ \\
March & $78 \pm 4(8)$ & $9 \pm 2(8)$ & $13 \pm 4(8)$ & $0.23 \pm 0.08(8)$ & $0.14 \pm 0.05(8)$ \\
June & $69 \pm 16(7)$ & $10 \pm 7(7)$ & $21 \pm 14(7)$ & $0.9 \pm 0.4(7)$ & $1.0 \pm 0.5(7)$ \\
\hline $\mathbf{1 9 9 9}$ & & & & \\
Late February & $46 \pm 17(3)$ & $10 \pm 2(3)$ & $44 \pm 17(3)$ & $0.02 \pm 0.02(3)$ & $0.04 \pm 0.02(3)$ \\
Late April & $65 \pm 20(3)$ & $16 \pm 13(3)$ & $19 \pm 11(3)$ & $0.8 \pm 0.7(3)$ & $0.4 \pm 0.4(3)$ \\
Late May & $60 \pm 7(4)$ & $7 \pm 11(4)$ & $33 \pm 11(4)$ & $3.0 \pm 0.6(4)$ & $4.0 \pm 3.5(3)$ \\
\hline
\end{tabular}




\section{Kinetic parameters of APA and turnover time of phosphate monoesters}

APA as a function of MUF-P fitted adequately the Michaelis and Menten model as illustrated in late May 1999 (Fig. 3 ). MUF-P concentrations from 50-100 $\mu \mathrm{M}$ enabled the activity to reach $\mathrm{V}_{\max }$ which was unchanged until $250 \mu \mathrm{M}$ in to contrast to recent findings of decreasing $\mathrm{V}_{\max }$ at high MUF-P (Sebastian and Niell, 2004). Although total $\mathrm{V}_{\max }$ increased from winter to late spring, $K_{m}$ values were similar in late February and May (Table 4) and significantly lower in late April. They were similar for all size fractions, according to the standard deviation of measurements. In late May, $\mathrm{K}_{\mathrm{m}}$ values of $0.2-1 \mu \mathrm{m}$ and dissolved fractions tended to be lower than those of $>1 \mu \mathrm{m}$ fraction. The estimated turnover times $\left(\mathrm{T}_{\mathrm{n}}\right)$ of phosphate monoesters were very high in late February (3000-4600 hours) whereas they dropped to 11 to 16 hours in late April and May (Table 4).

Fig. 3. Michaelis and Menten kinetics of total and size fractionated APA in late May 1999.

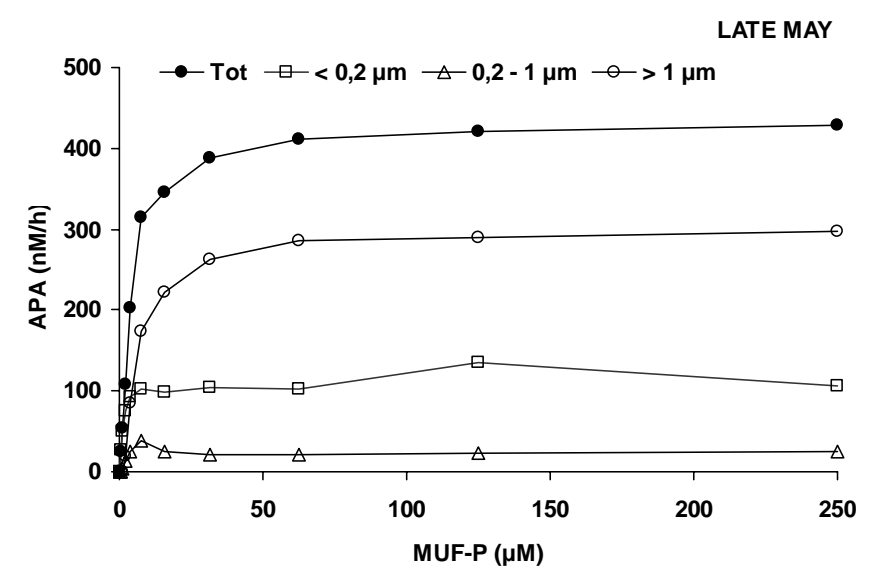

\section{Phosphate-enrichment bioassays}

For all bioassays, phosphate in both control and enriched samples decreased to low or undetectable values at the end of incubation (Fig. 4). The consumption of phosphate in phosphate enriched samples induced a strong increase in chl $a$ relative to the control at each period. The same results were obtained for primary production (see Labry et al., 2002). The estimated specific phytoplankton APA greatly increased in the phosphate unenriched controls relative to their initial values whereas it decreased in the phosphate enriched sample in late February and April (Fig. 4). In late May, the initial decrease in both control and phosphate 
enriched samples cannot be explained. However, the specific APA showed a great increase thereafter in the control whereas it decreased in the enriched sample.

Table 4. Turnover time $\left(T_{n}\right)$ of phosphate monoesters $(h)$ and kinetic parameters $\left(K_{m}: \mu M, V_{\text {max }}: n M h^{-1}\right)$ of APA size fractions in the Gironde plume mixed layer in 1999. Values in brackets are the standard deviations.

\begin{tabular}{|c|c|c|c|c|c|c|c|c|c|c|c|}
\hline & \multirow[t]{2}{*}{$T_{n}$} & \multicolumn{2}{|c|}{ Total } & \multicolumn{2}{|c|}{$<0.2 \mu \mathrm{m}$} & \multicolumn{2}{|c|}{$<1 \mu \mathrm{m}$} & \multicolumn{2}{|c|}{$0.2-1 \mu \mathrm{m}$} & \multicolumn{2}{|c|}{$>1 \mu \mathrm{m}$} \\
\hline & & $\mathbf{K}_{\mathbf{m}}$ & $\mathbf{V}_{\max }$ & $\mathbf{K}_{\mathbf{m}}$ & $\mathbf{V}_{\max }$ & $\mathbf{K}_{\mathbf{m}}$ & $\mathbf{V}_{\max }$ & $\mathbf{K}_{\mathbf{m}}$ & $\mathbf{V}_{\max }$ & $\mathbf{K}_{\mathbf{m}}$ & $\mathbf{V}_{\max }$ \\
\hline \multirow[t]{4}{*}{ Late Feb. } & 4585 & 9.72 & 2.12 & 7.87 & 0.28 & 6.77 & 0.80 & - & - & - & - \\
\hline & & $(2.60)$ & (1.18) & (4.61) & $(0.044)$ & (2) & $(0.061)$ & - & - & - & - \\
\hline & 3021 & 4.41 & 1.46 & 6.98 & 0.64 & 5.07 & 1.09 & - & - & - & - \\
\hline & & $(1.40)$ & $(0.10)$ & (1.12) & $(0.031)$ & (1.9) & (0.088) & - & - & - & - \\
\hline \multirow[t]{2}{*}{ Late April } & 16 & 0.43 & 26.3 & - & - & 1.32 & 8.86 & - & - & 0.189 & 17.58 \\
\hline & & $(0.11)$ & $(0.48)$ & - & - & $(0.6)$ & $(0.54)$ & - & - & (0.059) & (0.19) \\
\hline \multirow[t]{4}{*}{ Late May } & 11 & 4.68 & 444 & 1.00 & 108 & 1.18 & 133 & 2.09 & 26 & 9.00 & 321 \\
\hline & & $(0.49)$ & (10) & $(0.13)$ & (2.6) & (0.18) & (3.8) & (0.9) & (2.5) & (1.7) & (15) \\
\hline & 13 & 6.06 & 477 & 1.31 & 126 & 1.82 & 163 & 3.19 & 30 & 13.2 & 320 \\
\hline & & $(0.45)$ & (8) & $(0.10)$ & (1.98) & $(0.27)$ & (4.7) & (2.1) & (5.7) & (3.4) & (22) \\
\hline
\end{tabular}


Fig. 4. Evolution of chl $a$ (full line), phosphate (dashed line) on the left and specific phytoplankton APA on the right in control (open circle) and phosphate enriched samples (filled circle) during bioassays conducted from late February to late May 1999 on Gironde plume waters.
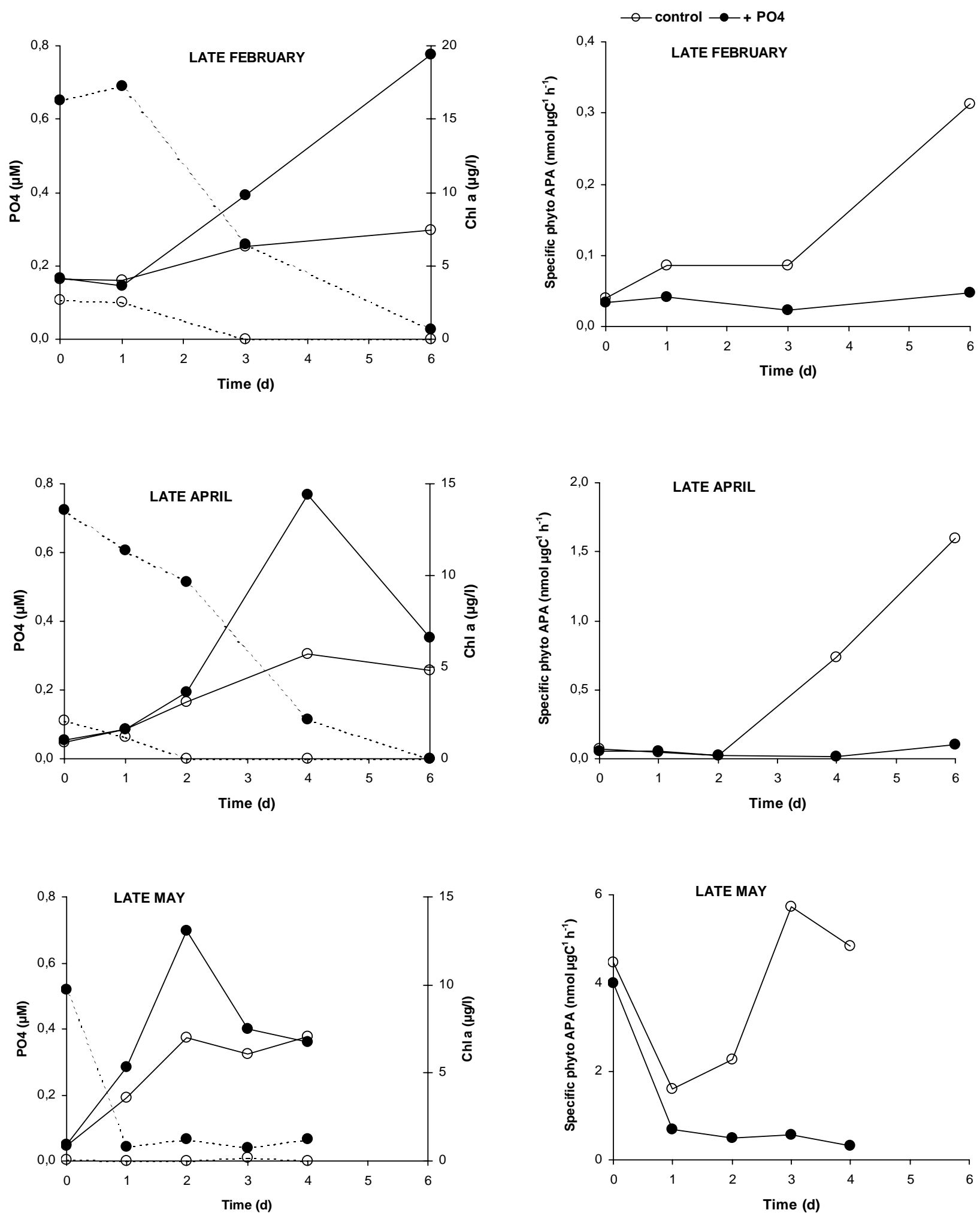


\section{DISCUSSION}

\section{Seasonal evolution of phosphorus and total APA}

The same seasonal evolution in phosphate found in 1998 and 1999 and matching previous investigations (Artigas, 1998; Herbland et al., 1998) indicates that the same seasonal pattern occurs year by year. The highest phosphate values observed in early winter corresponded to wind-driven vertical mixing, high inputs from the Gironde inflow and low biological activities. The decrease to an undetectable level thereafter $(<0.02 \mu \mathrm{M})$ corresponded to the consumption by late winter phytoplankton blooms (Table 1, Labry et al., 2001; 2002). In spring, the phosphate fluxes from the Gironde decreased (Michel et al., 2000) and as phytoplankton became more $\mathrm{P}$ deficient, the low phosphate supplied by freshwaters was immediately consumed. DOP still showed relatively high concentrations throughout the year even when the phosphate was low, as already observed in coastal waters (Monaghan and Ruttenberg, 1999), in the open ocean (Karl and Tien, 1997) and in lakes (Chrost and Overbeck, 1987). Then DOP originating either from Gironde inputs or from in situ production through food web processes (cell death, grazing...) represents the largest reservoir of dissolved $\mathrm{P}$ available for microorganisms after the late winter bloom. In these circumstances the lability of the DOP pool is of great importance for microorganisms and DOP in the Gironde plume waters could be composed of significant amounts (11 to $65 \%$ ) of easily hydrolysable compounds. This range of variable contributions has already been found in estuarine (0-56 \% Hernandez et al., 2000), coastal waters (19-50 \% Solorzano, 1978) and is well-known in lakes (0-60 \% Chrost et al., 1984). These changes, the disappearance of $\mathrm{PO}_{4}$ and the maintenance of DOP were linked to a large seasonal increase (mean factor of 39 in 1998 and 44 in 1999) in total APA from winter to late spring for both years. According to the seasonal increase in temperature $\left(5^{\circ} \mathrm{C}\right.$ in 1998 and $7{ }^{\circ} \mathrm{C}$ in 1999) and usual phosphatase $\mathrm{Q}_{10}$ values between 1.4 and 2.0 found in the field (Pettersson and Jansson, 1978) and in cultures (Huber and Kidby, 1984; Rivkin and Swift, 1980), the seasonal shift of total APA in the Gironde plume ( factor 40 ) cannot be attributed only to enzymatic activities being dependent on temperature, but the main explanation lies in the response of plankton communities to seasonal phosphate depletion. This is supported by the parallel drop in phosphate monoester turnover time, indicating that this pool was rapidly hydrolysed and recycled by plankton communities. Thus, all this evidence highlights the potential use of DOP as a source of phosphorus by plankton communities in spring. As APA was found to be a good indicator of 
phytoplankton P limitation (Healey and Henzel, 1980), higher APA found after late winter confirms that algal growth was phosphorus limited at the end of the winter blooms and in spring. However the high increase in APA was not reflected by the evolution of phosphate monoesters and DOP. The dynamic of DOP formation, supply and degradation is very complex because of its heterogeneity coming from their various and variable origins (river supplies, algal excretion, cell lysis...), the largely unknown degradation processes (chemical and enzymatic) of the refractory DOP to easily hydrolysable compounds, and the fast recycling of these compounds like in spring just after their formation. All of this could explain the inexistant relation between APA and DOP which is a common finding in such studies.

\section{Dissolved, Phytoplankton, and bacterioplankton APA}

In our study, the dissolved APA represented a significant part of the total activity (13 to 44 \%) even if high contributions were generally measured in lakes (14-61\% Wetzel, 1991). Higher contributions were also recorded in coastal (42-74\% Li et al., 1998) and in river waters (71-83 \% Hernandez et al., 2000) where dissolved activities were probably more disconnected from particulate ones. On the contrary, our dissolved activities were significantly correlated with particulate activities $(\mathrm{r}=0.859, \mathrm{p}<0.1)$ showing the same seasonal evolution. As these dissolved enzymes are relatively stable and remain active for several days (Chrost et al., 1986; Li et al., 1998), their effect on DOP cycling may be significant and they represent a source of mineral $\mathrm{P}$ when phosphate are depleted in the water column.

The composition of the particle associated APA, contributing to 56 to $87 \%$ of the total activity is a major question which must be explored. Since pure culture experiments indicated that both phytoplankton and bacteria exhibited APA (Currie and Kalff, 1984; Martinez and Azam, 1993), discrimination between algal and bacterial activities by selective filtration was achieved even though it may include errors as the size of the two groups could overlap. In our samples, the low contributions of $<1 \mu \mathrm{m} \operatorname{chl} a$ to the total chl $a$ and the weak cyanobacteria biomass indicated the lack of $<1 \mu \mathrm{m}$ autotrophic microorganisms. It has been confirmed by insignificant zeaxanthin levels, the biomarker pigment of cyanobacteria, found in late winter 2000 and in spring 1998 and 1999 during parallel investigations (Lampert 2001). Moreover particle-attached bacteria whose cell-specific enzymatic activities could be high (Karner and 
Herndl, 1992; Middelboe et al., 1995) were insignificant in winter 1999 (less than 3 \% of total bacterial biomass), less than $20 \%$ during spring and only 3 to 6\% during late spring according to previous studies in the same area (Artigas, 1998). Finally, to test if the overlap of the size spectra of bacteria and phytoplankton affected their APA estimation, comparisons of $>1 \mu \mathrm{m}$ APA/0.2-1 $\mu \mathrm{m}$ APA ratio (which included the sizing effect) with Cphyto/Cbact ratio obtained by size independant mesurements (eg total chl $a$ and bacterial count) showed that these ratios correlated significantly $(\mathrm{r}=0.513, \mathrm{n}=46, \mathrm{p}<0.1)$. This correlation could reasonably suggest that $>1 \mu \mathrm{m}$ APA and 0.2-1 $\mu \mathrm{m}$ APA represented respectively the bulk of phytoplankton and bacteria throughout the studied period.

Our results show that both communities contributed to particulate APA but that algae were always the major contributors whatever the bloom period. This dominance deduced from maximal activities $\left(\mathrm{V}_{\max }\right)$ could be different when considering actual APA i.e. at in situ hydrolysable DOP. It could be estimated in our study from kinetic parameters $\left(\mathrm{K}_{\mathrm{m}}, \mathrm{V}_{\max }\right)$ and phosphate monoesters. Since the latter (range 0.024-0.135 $\mu \mathrm{M}$ ) were always below the estimated $K_{m}$ for all size fractions (range 0.189-13.2 $\mu \mathrm{M}$ ), the difference between the fractionation deduced from $\mathrm{V}_{\max }$ and that deduced from actual APA depended largely on the difference between $K_{m}$ values. No significant discrepancy was found, except in late spring. However, even if bacterial enzymes had higher affinities to substrate in this case, estimated actual phytoplankton APA prevailed (2.5-3.8 $\mathrm{nM} \mathrm{h}^{-1}$ ) over bacterial APA (0.9-1.3 $\left.\mathrm{nM} \mathrm{h}^{-1}\right)$. Therefore, the few estimations of actual APA do not change the conclusions deduced from $\mathrm{V}_{\max }$ fractionation and confirm the dominance of algal APA. It is difficult to compare our results with those of other authors because of the numerous methods (Hoppe 2003) used i.e. different substrates used with the colorimetric or fluorimetric method, measurement at saturating substrate concentration $\left(\mathrm{V}_{\max }\right)$ or at trace concentration, incubation conditions at natural $\mathrm{pH}$ and temperature or at optimal values for enzyme activities... However extensive studies in lakes (Berman, 1970; Chrost and Overbeck, 1987) and rivers (Boon, 1993) have shown that both communities were alternately major contributors of particulate APA, with higher algal contributions during seasonal blooms. Thingstad et al. (1993) showed that there may have been a bacterial dominance in a Norwegian fjord. Within the Gironde plume, the dominance of algal APA throughout the winter and spring stemmed from a permanent greater algal biomass than bacterial biomass (Table 1). When divided by biomass (Cphyto and Cbact), specific APA results demonstrated that both communities had the same enzymatic 
potentialities for the hydrolysis of DOP. The same conclusions for bacterial and phytoplankton species, isolated from lakes and grown in P limited continuous cultures have also been drawn (Currie and Kalff, 1984). Other authors (Chrost and Overbeck, 1987) recorded higher specific bacterial APA although phytoplankton was P limited. In this study the bacteriawere $\mathrm{C}$ limited and attracted by the organic part of the DOP. This is often the case for bacteria (Hoppe 2003). Parallel phosphate enrichment bioassays conducted on bacteria in 1999 (See Labry et al., 2002) revealed that they were P limited in late May. However throughout the study period, specific bacterial APA like algal APA was strongly related to $\mathrm{PO}_{4}$ (See below).

\section{In situ and in vitro regulation of APA}

The regulation of APA by phosphate was demonstrated by an inverse hyperbolic relationship between APA, specific algal or bacterial APA, and phosphate (Fig. 5) with a transition between high and low activities occurring for 0.05-0.1 $\mu \mathrm{M}$. It has usually been found in $\mathrm{P}$ limiting environments for APA (Ammerman, 1991; Nausch, 1998) and specific phytoplankton APA (Siuda and Chrost, 1987) with a similar threshold for the stimulation of phosphatase enzyme production. But it has not been reported as regards bacteria to our knowledge. In contrast, no relation with phosphate was recorded for bacteria or associated with either the constitutive nature of the bacterial alkaline phosphatases (Siuda and Chrost, 1987) or the C requirement of bacteria, which would focus on organic C compounds simultaneously produced by APA, rather than P requirements (Hoppe and Ullrich, 1999). This regulation observed at a seasonal scale was also true for phytoplankton at a time scale of a few days: the induction of algal phosphatase synthesis occurred in phosphate depleted controls whereas a repression was observed in phosphate enriched samples (Fig. 4). As previously reported for freshwater and marine algal species, the high biochemical adaptation capacity of phytoplankton to low phosphate availability must be emphasized. We did not investigate bacterial alkaline phosphatase regulation in bioassays but previous studies (Huang et al., 1998) have produced the same responses. Thus, the seasonal increase in in situ specific APA arose from both long-term seasonal changes in populations and their short-term biochemical adaptation. 
The induction of algal phosphatase synthesis in $\mathrm{P}$ unenriched controls linked to a substantial increase in chl $a$ and primary production in phosphate enriched samples confirms that APA is a good physiological indicator of phytoplankton phosphorus deficiency within the Gironde plume. Moreover, the gradual seasonal increase in in situ specific APA from winter to late spring seems to indicate a progression from moderate to severe phosphorus limitation. The multiply factor in specific APA in bioassays between the beginning and the end of incubation in late May was found to be the lowest (Fig. 4) which could mean that phytoplankton cells may have reached their maximum induction capacities as regards enzyme synthesis in late May, the sign of severe phosphorus limitation. 
Fig. 5. Relationship between particulate APA size fractions (a), specific phytoplankton APA (b), specific bacterial APA (c) and phosphate for in situ measurements conducted both in 1998 and 1999.
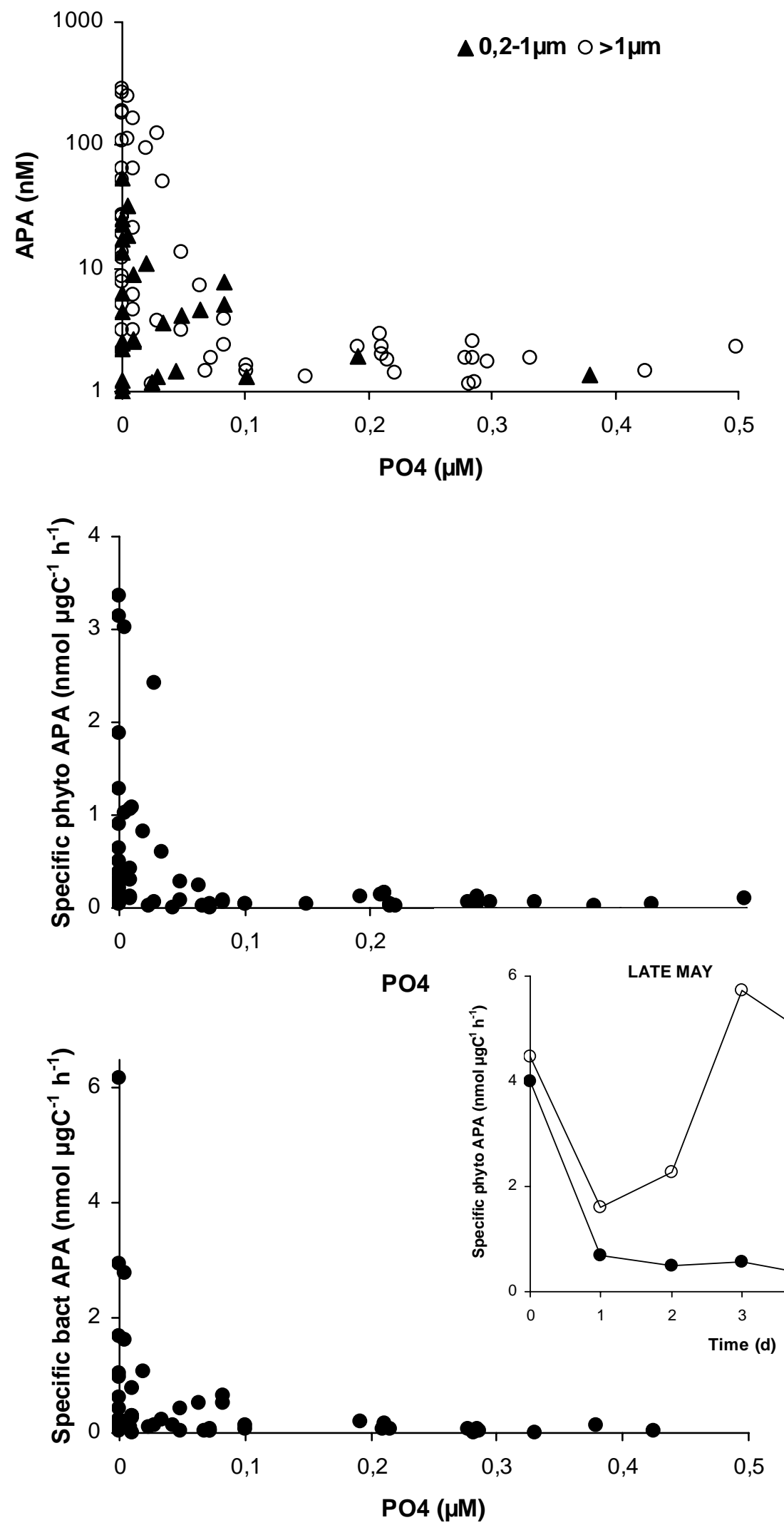


\section{ACKNOWLEDGEMENTS}

This research was supported by the French "Programme National Environnement Côtier"atlantic working site and "Programme National sur le Déterminisme du Recrutement"GLOBEC. We wish to thank Martine Breret, Françoise Mornet and Christophe Arnaud respectively for their assistance regarding bacterial counts, the analysis of DOP and phosphate monoesters.

\section{REFERENCES}

Ammerman, J.W., Azam, F., 1985. Bacterial 5'-nucleotidase in aquatic ecosystems: a novel mechanism of phosphorus regeneration. Sci. 227, 1338-1340.

Ammerman, J.W., 1991. Role of ecto-phosphohydrolases in phosphorus regeneration in estuarine and coastal ecosystems. In: Chrost R.J. (Ed.), Microbial enzymes in aquatic environments. Springer-Verlag, New York., pp. 165-186.

Artigas, L.F., 1998. Seasonal variability in microplanktonic biomasses in the Gironde dilution plume (Bay of Biscay) : relative importance of bacteria. Oceanol. Acta 21, 563-580.

Berman, T., 1970. Alkaline phosphatases and phosphorus availability in Lake Kinneret. Limnol. Oceanogr. 15, 663-674.

Boon, P.I., 1993. Organic matter degradation and nutrient regeneration in Australian fresh waters: III. Size fractionation of phosphatase activity. Archiv Hydrobiol. 126, 339-360.

Brooks, S.P.J., 1992. A simple computer program with statistical tests for the analysis of enzyme kinetics. Biotech. 13, 906-911.

Caron, D.A., 1983. Technique for enumeration of heterotrophic and phototrophic nanoplankton, using epifluorescence microscopy, and comparison with other procedures. Appl. Environ. Microbiol. 46, 491-498.

Cembella, A.D., Antia, N.J. Harrison, P.J., 1984. The utilization of inorganic and organic phosphorus compounds as nutrients by eukaryotic microalgae: a multidisciplinary perspective: Part 1. CRC Crit. Rev. in Microbiol. 10, 317-391.

Chrost, R.J., Siuda, W., Halemejko, G.Z., 1984. Long term studies on alkaline phosphatase activity (APA) in a lake with fish-aquaculture in relation to lake eutrophication and phosphorus cycle. Archiv. Hydrobiol. Suppl. 70, 1-32. 
Chrost, R.J., Siuda, W., Albrecht, D., Overbeck, J., 1986. A method for determining enzymatically hydrolysable phosphate (EHP) in natural waters. Limnol. Oceanogr. 31, 662-667.

Chrost, R.J., Overbeck, J., 1987. Kinetics of alkaline phosphatase activity and phosphorus availability for phytoplankton and bacterioplankton in Lake Plußsee (North German Eutrophic Lake). Microb. Ecol. 13, 229-248.

Currie, D.J., Kalff, J., 1984. A comparison of the abilities of freshwater algae and bacteria to acquire and retain phosphorus. Limnol. Oceanogr. 29, 298-310.

Delmas, D., Legrand, C., Bechemin, C., Collinot, C., 1994. Exoproteolytic activity determined by flow injection analysis : its potential importance for bacterial growth in coastal marine pond. Aquat. Living Resour. 7,17-24.

Fitzgerald, G.P., and Nelson, T.C., 1966. Extractive and enzymatic analyses for limiting or surplus phosphorus in algae. J. Phycol. 2, 32-37.

Gage, M.A., and Gorham, E., 1985. Alkaline phosphatase activity and cellular phosphorus as an index of the phosphorus status of phytoplankton in Minnesota lakes. Fresh. Biol. 15, 227-233.

Gambin, F., Bogé, G., Jamet, D., 1999. Alkaline phosphatase in a littoral Mediterranean marine ecosystem: role of the main plankton size classes. Mar. Environ. Res. 47, 441456.

Gonzalez-Gil, S., Keafer, B.A., Jovine, R.V.M., Aguilera, A., Lu, S., Anderson, D.M., 1998. Detection and quantification of alkaline phosphatase in single cells of phosphorus-starved marine phytoplankton. Mar. Ecol. Prog. Ser. 164, 21-35.

Healey, F.P., Henzel, L.L., 1980. Physiological indicators of nutrient deficiency in lake phytoplankton. Can. J. Fish. Aquat. Sci. 37, 442-453.

Herbland, A., Delmas, D., Laborde, P., Sautour, B., Artigas, F., 1998. Phytoplankton spring bloom of the Gironde plume waters in the Bay of Biscay: early phosphorus limitation and food-web consequences. Oceanol. Acta. 21, 279-291.

Hernandez, I., Pérez-Pastor, A., Pérez Lloréns, J.L., 2000. Ecological significance of phosphomonoesters and phosphomonoesterase activity in a small Mediterranean river and its estuary. Aquat. Ecol. 34, 107-117.

Hoppe, H.G., 1983. Significance of exoenzymatic activities in the ecology of brackish water: measurements by means of methylumbelliferyl-substrates. Mar. Ecol. Prog. Ser. 11, 299308. 
Hoppe, H.G., 2003. Phosphatase activity in the sea. Hydrobiol. 493, 187-200.

Hoppe, H.G., Ullrich, S., 1999. Profiles of ectoenzymes in the Indian Ocean: phenomena of phosphatase activity in the mesopelagic zone. Aquat. Microb. Ecol. 19, 139-148.

Huang, C.T., Xu, K.D., McFeters, G.A., Stewart, P.S., 1998. Spatial patterns of alkaline phosphatase expression within bacterial colonies and biofilms in response to phosphate starvation. Appl. Environ. Microbiol. 64, 1526-1531.

Huber, A.L., Kidby, D.K., 1984. An examination of the factors involved in determining phosphatase activities in estuarine water. 1. Analytical procedures. Hydrobiol. 111, 3-11.

Karl, D.M., Tien, G., 1997. Temporal variability in dissolved phosphorus concentrations in the subtropical North Pacific Ocean. Mar. Chem. 56, 77-96.

Karner, M., Herndl, G.J., 1992. Extracellular enzymatic activity and secondary production in free-living and marine-snow-associated bacteria. Mar. Biol. 113, 341-347.

Kobori, H., Taga, N., 1979. Phosphatase activity and its role in the mineralization of organic phosphorus in coastal sea water. J. Exp. Mar. Biol. Ecol. 36, 23-39.

Labry, C., Herbland, A., Delmas, D., Laborde, P., Lazure, P., Froidefond, J.M., Jegou, A.M., Sautour, B., 2001. Initiation of winter phytoplankton blooms within the Gironde plume waters in the Bay of Biscay. Mar. Ecol. Prog. Ser. 212, 117-130.

Labry, C., Herbland, A., Delmas, D., 2002. The role of phosphorus on planktonic production of the Gironde plume waters in the Bay of Biscay. J. Plankton Res. 24, 97-117.

Lampert, L., 2001. Dynamique saisonnière et variabilité pigmentaire des populations phytoplanctoniques dans l’Atlantique Nord (Golfe de Gascogne). PhD Thesis, Université de Bretagne Occidentale, Brest, France.

Li, H., Veldhuis, M.J.W., Post, A.F., 1998. Alkaline phosphatase activities among planktonic communities in the northern Red Sea. Mar. Ecol. Prog. Ser. 173, 107-115.

Longhurst, A., 1998. Ecological geography of the sea. San Diego: Academic Press.

Martinez, J., Azam, F., 1993. Periplasmic aminopeptidase and alkaline phosphatase activities in a marine bacterium: implications for substrate processing in the sea. Mar. Ecol. Prog. Ser. 92, 89-97.

Michel, P., Boutier, B., Chiffoleau, J.F., 2000. Net fluxes of dissolved arsenic, cadmium, copper, zing, nitrogen and phosphorus from the Gironde estuary (France) : seasonal variations and trends. Estuar. Coast. Shelf Sci. 51, 451-462. 
Middelboe, M., Sondergaard, M., Letarte, Y., Borch, N.H., 1995. Attached and free-living bacteria : production and polymer hydrolysis during a diatom bloom. Microb. Ecol. 29, 231-248.

Monaghan, E.J., Ruttenberg, K.C., 1999. Dissolved organic phosphorus in the coastal ocean: reassessment of available methods and seasonal phosphorus profiles from the Eel River Shelf. Limnol. Oceanogr. 44, 1702-1714.

Myklestad, S., Sakshaug, E., 1983. Alkaline phosphatase activity of Skeletonema costatum populations in the Trondheimsfjord. J. Plankton Res. 5, 557-564.

Nausch, M., 1998. Alkaline phosphatase activities and the relationship to inorganic phosphate in the Pomeranian Bight (southern Baltic Sea). Mar. Ecol. Prog. Ser. 16, 87-94.

OSPAR Commission, 2000. Quality Status Report 2000 : Region IV-Bay of Biscay and Iberian coast, London: OSPAR Commission.

Pettersson, K., Jansson, M., 1978. Determination of phosphatase activity in lake water - a study of methods. Verh. Internat. Verein. Limnol. 20, 1226-1230.

Porter, K.G., Feig, Y.S., 1980. The use of DAPI for identifying and counting aquatic microflora. Limnol. Oceanogr. 25, 943-948.

Rivkin, R.B., Swift, E., 1980. Characterization of alkaline phosphatase and organic phosphorus utilization in the oceanic dinoflagellate Pyrocystis noctiluca. Mar. Biol. 61, $1-8$.

Rose, C., Axler, R.P., 1998. Uses of alkaline phosphatase activity in evaluating phytoplankton community phosphorus deficiency. Hydrobiol. 361, 145-156.

Sautour, B., Artigas, L.F., Delmas, D., Herbland, A., Laborde, P., 2000. Grazing impact of micro- and mesozooplankton during a spring situation in coastal waters off the Gironde estuary. J. Plankton Res. 22, 531-552.

Sebastian, M., Aristegui, J., Montero, M.F. Niell, F.X., 2004. Kinetics of alkaline phosphatase activity, and effect of phosphate enrichment: a case study in the NW African upwelling region. Mar. Ecol. Prog. Ser. 270, 1-13.

Sebastian, M., Niell, F.X., 2004. Alkaline Phosphatase activity in marine oligotrophic environments: implications of single-substrate addition assays for potential activity estimations. Mar. Ecol. Prog. Ser. 277, 285-290.

Siuda, W., Chrost, R.J., 1987. The relationship between alkaline phosphatase (APA) activity and phosphate availability for phytoplankton and bacteria in Eutrophic lakes. Acta Microbiol. Pol. 36, 247-257. 
Solorzano, L., 1978. Soluble fractions of phosphorus compounds and alkaline phosphatase activity in Loch Creran and Loch Etive, Scotland. J. Exp. Mar. Biol. Ecol. 34, 227-232.

Strickland, J.D.H., Parsons T.R., 1972. A practical handbook of seawater analysis. Bull. Fish. Res. Board Can. 167.

Thingstad, T.F., Skjoldal, E.F., Bohme, R.A., 1993. Phosphorus cycling and algal-bacterial competition in Sandsfjord, western Norway. Mar. Ecol. Prog. Ser. 99, 239-259.

Valderrama, J.C., 1981. The simultaneous analysis of total nitrogen and total phosphorus in natural waters. Mar. Chem. 10, 109-122.

Varela, M., 1996. Phytoplankton Ecology in the Bay of Biscay. Scientia. Mar. 60, 45-53.

Wetzel, R.G., 1991. Extracellular enzymatic interactions : storage, redistribution, and interspecific communication. In: Chrost R.J. (Ed.), Microbial enzymes in aquatic environments. Springer-Verlag, New York, pp. 6-28.

Wright, S.W., Jeffrey S.W., Mantoura, R.F.C., 1997. Evaluation of methods and solvents for pigment extraction. In: Jeffrey S.W., Mantoura R.F.C., Wright S.W. (Eds.), Phytoplankton pigments in oceanography: guidelines to modern methods. UNESCO Publishing, Paris, pp. 261-282. 
Table 1. Mean concentrations $\pm 95 \%$ confidence interval of chl $a$, bacterial counts, phytoplankton and bacterial carbon, assuming respectively a constant C:chl $a$ w:w ratio of 50:1 and a constant cell content of $16 \mathrm{fg} \mathrm{C}$, within the mixed layer of the Gironde plume in 1998 and 1999. Values in brackets are number of samples.

Table 2. Mean concentrations $\pm 95 \%$ confidence interval $(\mu \mathrm{M})$ of phosphate, DOP, POP and $\mathrm{PO}_{4}$ monoesters within the mixed layer of the Gironde plume in 1998 and 1999. Because of homogeneous vertical distribution, $\mathrm{PO}_{4}$ monoesters were averaged within the entire water column. Values in brackets are number of samples.

Table 3. Relative size contribution (mean $\pm 95 \%$ confidence interval) to total APA and specific phytoplankton and bacterial APA within the mixed layer of the Gironde plume in 1998 and 1999. Values in brackets are number of samples.

Table 4. Turnover time $\left(\mathrm{T}_{\mathrm{n}}\right)$ of phosphate monoesters $(\mathrm{h})$ and kinetic parameters $\left(\mathrm{K}_{\mathrm{m}}: \mu \mathrm{M}\right.$, $\mathrm{V}_{\max }: \mathrm{nM} \mathrm{h^{-1 }}$ ) of APA size fractions in the Gironde plume mixed layer in 1999. Values in brackets are the standard deviations.

Fig. 1. Study site with locations of the different stations (some are surimposed) for all cruises in 1998 and 1999.

Fig. 2. Profiles of phosphate and total APA in the Gironde plume in 1998 (filled circle) and 1999 (open circle). The mixed layer was located at 10-20 meters throughout the study period. Be attentive to scales.

Fig. 3. Michaelis and Menten kinetics of total and size fractionated APA in late May 1999.

Fig. 4. Evolution of chl a (full line), phosphate (dashed line) on the left and specific phytoplankton APA on the right in control (open circle) and phosphate enriched samples (filled circle) during bioassays conducted from late February to late May 1999 on Gironde plume waters. Be attentive to scales.

Fig. 5. Relationship between particulate APA size fractions (a), specific phytoplankton APA (b), specific bacterial APA (c) and phosphate for in situ measurements conducted both in 1998 and 1999. 
